\title{
Tax Disputes Resolution In Nigeria: Going Beyound The Traditional Court And Administrative Resolution System
}

\author{
Peter Ademu Anyebe \\ LL.M (UNILAG), MPhil (OAU, Ile-Ife), PhD in view (OAU, Ile-Ife), BL \\ Nigerian Institute Of Advanced Legal Studies, Unilag Campus, Lagos \\ Senior Research Fellow, H.O.D., African And Comparative Law
}

\begin{abstract}
It is the requirement of law that tax is paid. Therefore, the discharge of tax obligation in Nigeria is not by choice. In the process of the tax authorities who are authorized under the law to collect taxes from tax payers, disputes arise. The paper reveals that in its bid to lessen the incidents of tax evasion in Nigeria, the Federal Government carried out a major reform in its tax regime. Thus, the Tax Appeal Tribunal (TAT) was established to ensure fairness and transparency of the tax system through a quick and efficient method of dispensing justice. Appeal from there lies to the Federal High Court on point of law. However, there is the unresolved problem of the constitutionality of TAT in its powers and jurisdiction in resolving tax disputes with Federal High Court (FHC). Furthermore, the paper reveals that tax disputes are not arbitrable under Nigerian law. It is the argument of this paper that although the courts are recognized as the most visible dispute arbiter, it is not always the most effective or efficient method. Therefore, it is further the argument of this paper that Nigeria's tax objection procedures as governed by statutory rules should incorporate Alternative Dispute Resolution mechanism as practiced in other jurisdictions. The paper recommends that the necessary amendments should be made to enable TAT and FHC at their levels to encourage the use of early dispute resolution (EDR) and alternative dispute resolution (ADR), particularly mediation in the settlement of tax disputes brought before them. The introduction of VAIDS (Voluntary Assets and Income Declaration Scheme) by the Federal Government of Nigeria is in line with global best practices on non-disclosure of informal and declaration of assets. The paper concludes among others that Nigeria, as a country cannot operate in isolation, hence the introduction of ADR in its tax dispute resolution processes should be imminent and mandatory.
\end{abstract}

Key Words: Tax, Tax Disputes, Arbitration, Mediation, Negotiation (ADR), VAIDS

Disputes between the Federal Inland Revenue Services (FIRS) and tax payers arise when tax payers fail to agree with an FIRS finding, refuses to file tax returns, or refuses to comply with its request for information. In other words, tax dispute arises when there is disagreement between taxpayers and tax authorities, such as the Federal Inland Revenue Service (the FIRS) or a State Board of Internal Revenue, over tax liability or otherwise of a taxpayer. The context of this dispute may relate to an inquiry into a return, an audit, or pre-return which could be founded on pre-or post transaction basis. Such disputes must be settled in one way or the other. $^{1}$

Although, the Nigerian legal system has provides a vehicle for peaceful resolution of tax disputes, it has often operated in less than ideal fashion The problems in settling tax disputes

\footnotetext{
${ }^{1}$ Jirinwayo Jude ODINKONIGBO, “Does Nigeria Follow The Contemporary Global Trend in Tax Dispute Resolution
} Strategy"?, (2014) 154 The Nigerian Juridical Review, Vol. 12, at 155 
are well known: complexity of the procedures, financial costs of litigation, the question of the constitutionality of TAT, the unarbitrability of tax disputes, delay of legal services, among others have led credence to finding a more alternative means of settling tax disputes in Nigeria to be in consonance with what obtains in other developed nations. Due to the fact that tax disputes are not arbitrable in Nigeria, the paper advocates that other types of ADR, i.e. mediation and negotiation should be resorted more in resolving its tax disputes. In addition, the Nigerian general court system such as the Federal High Court (FHC), or even the State High Court, in cases where they may exercise jurisdiction, do not have specialized tax chambers of the courts for the purpose of handling tax disputes. ${ }^{2}$ This is in line with the prevailing global trend which many developed countries use in resolving tax disputes. Most adopt ADR as part of their internal administrative tax dispute resolution mechanisms, simply for the purpose of faster resolution of tax disputes. ${ }^{3}$ Furthermore, the signing of the Executive Order by the Vice President of VAIDS as a tax amnesty is in line with the proposal of the Organization for Economic Cooperation and Development (OECD) in 2010.

The purpose of this paper is to de-emphasize the use of traditional courts and administrative tribunals for settling tax disputes in Nigeria. The paper therefore canvasses for the adoption of ADR for effective and quicker resolution of tax disputes and according to Odinkonigbo", "this will help in appreciate if Nigeria is keeping with global trend, despite our peculiarities and differences, which must be considered by our local tax authorities." It is also to highlight the introduction of the innovative Executive Order signed by the Acting President of Nigeria in bringing into 'birth' VAIDS.

In achieving the above objectives, the paper focuses on a brief general overview of the judicial dispute resolution in Nigeria in Part II as a mode of settling disputes in Nigeria and why it may not be adequate to adopt it as tax dispute resolution mechanism in Nigeria. Part III examines tax dispute resolution structure in Nigeria which discusses the FHC and TAT as modes of tax resolution mechanisms in Nigeria. Part IV highlights using the ADR to resolve taxpayer disputes. This includes arbitration (which has pointed out clearly that tax matters in Nigeria are not arbitrable), negotiation and mediation. Part V highlights the newly introduced VAIDS (Voluntary Assets and Income Declaration Scheme), as an amnesty for tax defaulters, Part VI briefly discusses tax dispute resolutions in other jurisdictions notably, Australia and United States. Recommendations cover Part VII, while the conclusion follows in Part VIII.

\section{JUDICIAL DISPUTE RESOLUTION IN NIGERIA: AN OVERVIEW}

Nigeria adopts the adversarial system, being a member of the Commonwealth, as practiced in the United Kingdom, in resolving disputes between parties. It is a system for the attainment of justice according to law through the intervention of a supposedly neutral third party who through the interpretation of the law as a judge pronounces upon the rights, obligations and liabilities of each litigant before him. This procedure portends that justice must be dispensed according to the laid down rules of law. The outcome of such a system is perhaps undoubtedly legal justice, i.e. justice according to law. ${ }^{5}$

Therefore, the most common form of judicial dispute is litigation. Litigation is initiated when one party files suit against another. The proceedings are very formal and are governed by rules

${ }^{5}$ Dele PETERS “Alternatives to Litigation: Multi-Door Court House Concept”, in YUSUF (ed) Issues Administration in Nigeria, (Lagos: VDG International Press Limited,2008) at 435
} 
such as rules of evidence and procedure which are established by the legislature. The outcomes are decided by an impartial judge based on the factual question of the case and the applicable law. The verdict (or decision) of the court is binding not advisory. However, both parties have the right to appeal (against) the judgment to a higher court.

The adversarial system adopts by Nigeria is not perfect and has some problems. Oputa (as he then was) put the problems militating against dispensation of justice in Nigeria in clearer perspective thus:

The fact cannot be gainsaid that dispensation of justice in Nigeria today is plagued with delay arising from long adjournments, cumbersome and rigorous procedure, difficult and ambiguous rules of evidence and other several artificial obstacles. The effects of the foregoing are that in civil cases, litigants are often frustrated while in criminal cases, suspects are detained for years without formal trial. In addition to the above, the cost of litigation has soared and with the excruciating effect of inflationary trend on the economy, prosecuting suits and affording quality legal representation has become a nightmare. ${ }^{6}$

According to Ayua, it tends to elevate form over substance, no matter how much the judges insist in rhetoric "that justice is not a fencing game in which the parties engage in whirligig of technicalities. ${ }^{7}$ These complexities become more chronic and costly as litigation go up the judicial pinnacle, thereby making judicial proceedings both mysterious and daunting for most people. Secondly, many people consider the entire legal system as having too much root in English concepts and as, therefore, being basically a colonial relic. ${ }^{8}$ Furthermore, according to Ayua "many of these legal concepts have not been part of the African experience and therefore could not cover our existential realities...this tends to exclude the traditional community role of law in our indigenous societies which focused on better management of human relations through conciliation or compromise of disputes."

The challenge accruing from the afore analyzed issue therefore has been how to remove the delay attending the dispensation of justice in Nigeria by supplementing it with such other means that are simple, elegant, less costly and litigants friendly. ${ }^{10}$ This therefore calls for the adoption of ADR which advantages include: non-involvement of jury, expenses are kept down, its speedy, result is confidential, it is flexible and the parties have control over the processes. In addition, the overall purposes of ADR include among others improving access of litigants to the judicial system, reducing costs for litigants and the judicial system and obtaining better resolution of disputes. ${ }^{11}$

In view of the visible disadvantages of the adversarial system in Nigeria, tax disputes cannot be satisfactorily resolved through the traditional courts system.

${ }^{6}$ Celestine 0.OPUTA, "Human Rights in the Political and Legal Culture of Nigeria", (Nigeria Law Publications (1989), at 75

7 Ignatious AYUA, "Nigerian Legal Profession: Problems and Prospects", in Ayua (ed) Law, Justice and the Nigerian Society, NIALS Commemorative Series 1 (Lagos: Nigerian Institute of Advanced Legal Studies, 1995) at 6

8 Ibid

${ }^{9}$ Ibid

${ }^{10}$ Ibrahim Saad MOHAMMED, "An Overview of Alternative Dispute Resolution (ADR) in the Dispensation of Justice in Nigeria, Olanrewaju FAGBOHUN and Ben Dele OLOWORARAM (eds) Readings in Contemporary Law and Policy Issues: Essays in Honour of Dr. The Hon. Justice Iche N.Ndu, Chief Judge, Rivers (Port Harcourt: Institute of Human Capacity Development and Continuing Education, 2013) at 127

${ }^{11}$ American Bar Association Committee on Dispute Resolution, Washington, D.C 


\section{TAX DISPUTE RESOLUTION STRUCTURE IN NIGERIA}

Statutorily, the tax payer, be it corporate or individual files his or her or its returns to the FIRS. $^{12}$ The FIRS upon assessment of the taxpayer returns issues demand notice. A taxpayer aggrieved with FIRS assessment may within 30 days from the issuance of the assessment or demand file a Notice of Objection in writing demanding that the assessment be reviewed and revised. As a result, the FIRS may adopt any of the following: agrees with the taxpayer's objection or refuse to amend the initial amendment. In this case, the FIRS issue a Notice of Refusal to Amend (NORA) to the taxpayer. Within 30 days after receiving the NORA, the taxpayer may file an appeal to the Tax Appeal Tribunal (TAT) for review of the FIRS' stand. ${ }^{13}$ Further appeal from TAT lies to the Federal High Court on issues of law while a decision on point fact lies straight to the Court of Appeal rather than to the Federal High Court. A further appeal lies to the Court of Appeal and finally to the Supreme Court of Nigeria. ${ }^{14}$ The existing statutory framework for the resolution of tax disputes in Nigeria is as follows:

The establishment of the Tax Appeal Tribunal (TAT) pursuant to section 59 of the FIRS (Establishment) Act, 2007, with the mandate to deal with any action, decision, assessment, or demand notice by the FIRS in furtherance of its implementation of tax legislation. ${ }^{15}$ Appeal from decisions of the TAT on points of law lie to the Federal High Court. ${ }^{16}$ In addition, the Federal High Court has exclusive jurisdiction to deal with disputes connected with, or pertaining to the taxation of companies in Nigeria. ${ }^{17}$ Although the intention of the legislature is to create room for speedy dispensation of issues relating to taxation and revenue of the Federal Government, the conflict between the authority given to the Federal High Court and the TAT to deal with revenue matters, has raised a problem over which among them should have jurisdiction. In addition, tax disputes are not arbitrable in Nigeria.

It should be pointed out that TAT has jurisdiction over disputes arising from the Companies Income Tax, Petroleum Profit Tax, Personal Income Tax, Capital Gains Tax, Value Added Tax, Stamp Duties, Taxes and Levies. ${ }^{18}$ It is worthy to note that the provisions of any statute of limitation shall not apply to appeals brought before the Tribunal. ${ }^{19}$

\section{FEDERAL HIGH COURT (FHC)}

Federal High Court ${ }^{20}$ is one of the superior court of records in Nigeria. It was originally established in 1973 as the Federal Revenue Court by the Federal Revenue Court Decree 1973. The court had jurisdiction to try all matters relating to the revenue of the Federal Government. It was only renamed the Federal High Court on the $1^{\text {st }}$ day of October $1979 .{ }^{21}$ The court had civil and criminal jurisdiction in matters concerning the Federal Government revenue, and also exercising general commercial jurisdiction in cases concerning companies, banking, insurance, trademarks, patents, admiralty, custom and excise duties, e.t.c. ${ }^{22}$

\footnotetext{
12 Sections 41 and 44 of the Personal Income Tax Act, 1993 (as amended); and sections 53 and 55 of the Companies Income Tax Act, 2007 (as amended)

13 This is by virtue of Para. 14 of the $5^{\text {th }}$ Schedule to the FIRS Act

15 Fifth Schedule to the FIRS (Establishment) Act, 2007, para. 13

16 Ibid, para. 14

17 Section 251 (1) (b) of the Constitution o the Federal Republic of Nigeria, 1999, as amended

18 First Schedule to the FIRS Act, 2007

19 Ibid, para 2(1); see also the case of Oando Supply \& Trading Ltd. v. Federal Inland Revenue Service (2011) 4 TLRN 113-130

20 Section 249 (1) of the 1999 Constitution makes provision for the Establishment of the Court

${ }^{21}$ Section 230 (2), Constitution of the Federal Republic of Nigeria Act No. 25 of 1978

22 Section 7 of the Federal High Court Act, 1973
} 
The jurisdiction of the Federal High Court is specific and expressly limited by the 1999 Constitution of the Federal Republic of Nigeria, the Federal High Court Act, 1973 as amended and by enacting statutory provision. The Federal High Court being a creature of statute can only assume jurisdiction in cases and matters concerning the particular subject matters stipulated under section 251 (1) of the 1999 Constitution or any specific legislature vesting subject matter jurisdiction. However, the determining factor is the claim before the court that has to be looked at or examined to ascertain whether it comes within the jurisdiction conferred on the court. ${ }^{23}$

\section{THE TAX APPEAL TRIBUNAL (TAT)}

This is an administrative body for the enforcement of tax matters in Nigeria. It replaced the nullified VAT Tribunal through judicial declaration in the case of Stabilini Visioni v. FBIR ${ }^{24}$. It was established by section 59 of the Federal Inland Revenue Service (FIRS) Act, 2007. It provides in section 59 (1) that it shall have power to settle disputes arising from the operation of this Act and under the First Schedule. It has jurisdiction over disputes arising from the Companies Income Tax, Petroleum Profit Taxes, Personal Income Tax, Capital Gains Tax, Value Added Tax, Stamp Duties, Taxes and Levies. ${ }^{25}$ Its scope of powers covers settlement of dispute arising from the operations of the FIRS Act and other tax laws as spelt out in the First Schedule to the Act. Its powers also cover any other law for the assessment, collection and enforcement of revenue accruable to the Federal Government of Nigeria as made the National Assembly from time to time or regulations incidental to those laws, conferring any power any power, duty and obligation on the Service. Other laws include laws imposing taxes and levies within the Federal Capital Territory, laws imposing collection of taxes, fees and levies collected by government agencies and companies, including signature bonuses, pipeline fees, and penalties for gas flared, depot levies and licence fees for Oil Exploration Licence (OEL), Oil Mining Lease (OML) production licence, royalties, rents (productive and non-productive), fees for licence to operate drilling rigs, fees for oil pipeline licences, haulage fees and all other fees prevalent in the oil and gas industry.

Paragraph 20 (2) Fifth Schedule to the FIRS (Amendment) Act, 2007 explicitly provides for the power of the TAT as follows:

The Tribunal shall have power to:

i. Summons and enforce the attendance of the person and examine him on oath;

ii. Require the discovery and production of documents;

iii. Receive evidence on affidavits;

iv. Call for the examination of witnesses or documents;

v. Review its decisions;

vi. Dismiss an application for default or deciding matters exparte;

vii. Set aside any order or dismissal of any application for default or any order passed by it exparte; and

viii. Do anything which in the opinion of the Tribunal is incidental or ancillary to its functions.

Appeals before the tribunal must be held in public. ${ }^{26}$ Where its judgments are registered with the Registrar of the Federal High Court, it becomes as effective as the judgment of the Federal

\footnotetext{
${ }^{23}$ See: Adeyemi v. Opeyori (1976) 9-10 SC 31; Tukur v. Govt. of Gongola State (1989) 4 NWLR (pt. 116) SC 517; Western Steel Works v. Iron \& Steel Workers (1978) NWLR (pt. 49) 284

24 (2009) 13 NWLR (pt. 115) 561

25 First Schedule to the FIRS Act, 2007

26 Para. 15 (2) of the First Schedule
} 
High Court when it is on facts. ${ }^{27}$ Appeals from the decision of the Tribunal shall lie to the Federal High Court on issues of law and then to the Court of Appeal. ${ }^{28}$

\section{CONSTITUTIONAL STATUS OF TAX APPEAL TRIBUNAL}

The inauguration of the Tax Appeal Tribunal has not presented problems as to the powers of the executive arm in providing a mechanism for the administration of tax in Nigeria, but the seeming similarities with the jurisdiction of the Federal High Court as provided under section 251 of the Constitution of the Federal Republic of Nigeria has provided the highlights of controversies between the Tax Appeal Tribunal and the Federal High Court. ${ }^{29}$

In the first place, powers conferred on TAT as established under section 59 (1) of FIRS Act centre on the resolution of disputes involving the imposition and collection of taxes, and/or government revenues. Hence, by this provision, the powers of the TAT conflict with the powers conferred on the Federal High Court to exercise exclusive jurisdiction over matters relating to the Federal Government of Nigeria in relation to revenues of it or any agencies, and/or taxation payable to it.'

Section 251 of the Constitution of the Federal Republic of Nigeria provides as follows:

(1) Notwithstanding anything contained in this Constitution and in addition to such other jurisdiction as may be conferred upon it by an Act of the National Assembly, the Federal High Court shall have and exercise jurisdiction to the exclusion of any other court in civil causes and matters-

(a) Relating to the revenue of the Government of the Federation in which the said Government or any organ thereof or a person suing or being sued of the said Government is a party;

(b) Connected with or pertaining to the taxation of companies and other bodies established or carrying on business in Nigeria and all other persons subject to Federal taxation.

In NURTW \& Anor v. RTEAN \& Ors ${ }^{30}$, the Supreme Court held that section 251 of the Constitution clearly confers exclusive jurisdiction on the Federal High Court whenever civil causes and matters relating to the revenue of the Government of the Federation; taxation of companies or other bodies established for carrying on business in Nigeria; and/or persons liable to federal taxation are involved. An ordinary glance at the statutes and/or laws mentioned in the First Schedule to the FIRS Act will reveal the referred legislation or laws deal with the revenues of the Government of the Federation and taxation of persons liable to federal taxes in accordance with each of the statutes listed therein. Therefore, it is safe that the greater percentage of the subject covered by the statutes mentioned in the First Schedule to the FIRS Act relates to issues exclusively tried in the Federal High Court. ${ }^{31}$ Thus, tax practitioners are quite apprehensive as to whether the Nigerian Tax Appeal Tribunal (TAT) would suffer a similar fate as the extinct Value Added Tax Tribunal (VATT), which suffered premature extinction post the 1999 Constitution of Nigeria. ${ }^{32}$ Thus, in Stabilini Visionini Ltd . v.FBIR ${ }^{33}$, the Court of Appeal held that the VAT Tribunal was not an administrative tribunal, since appeals

\footnotetext{
27 Para 16 (2), ibid

28 Para 17 (1) \& (3) Fifth Schedule Policy and Globalization, (2014) at 150 vol. 29

30 (2012) LPELR, 7840

32 Agbonika Josephine Aladi ACHOR, op. cit. p. at 150 footnote 29

33 (2009) 13 NWLR (pt. 115) 200
}

${ }^{29}$ Agbonika Josephine Aladi ACHOR, Tax Dispute Resolution in Nigeria: A Storm in a Tea Cup, Journal of Law, 
from there did not lie to the Federal High Court, but to the Court of Appeal, and further, that section 20 of the VAT Act that had set up the VAT Tribunal was inconsistent with section 251 of the Constitution of the Federal Republic of Nigeria that had solely conferred jurisdiction of the federal revenue exclusively on the Federal High Court. Similarly, in Cadbury (Nig) Plc v. FBIR ${ }^{34}$, the FBIR had directed Cadbury to render VAT returns based on Cadbury's payment to its Parent Company in Britain. Upon Cadbury's refusal, FBIR instituted tax recovery proceedings before the VAT Tribunal. With FBIR success at the VAT Tribunal, Cadbury appealed against VAT Tribunal's jurisdiction to the Court of Appeal. The Court of Appeal sustained Cadbury's objection and held that the VAT Tribunal had no jurisdiction to entertain VAT issues since such tax issues touched on the exclusive jurisdiction of federal revenue, conferred solely upon the Federal High Court.

Omokri, JCA, echoing the principle in the case of N.P.A v. Enyamba ${ }^{35}$, held that:

By virtue of the provision of section 251 (1) (a) of the 1999 Constitution, the Federal High Court shall have exclusive jurisdiction to the exclusion of any other court in civil cases and matters relating to the revenue of the Federal Government of the Federation or any organ thereof of a person giving being used on behalf of the said Government as a party or the administration and control of the Federal Government or any of its agencies of the Federal Government.

However, going by the decision of Justice I.N.Buba in the case of Nigerian National Petroleum Corporation (NNPC) v. Tax Appeal Tribunal ${ }^{36}$, a lease of life has been given to TAT. Justice I.N.Buba held that the TAT jurisdiction did not interfere with the exclusive jurisdiction of the Federal High Court but was only an administrative body set up to determine preliminary matters before proceeding to the Federal High Court. He further held that the FIRSEA that established the TAT was fundamentally different from the VAT Tribunal Act that purportedly set up the defunct VAT Tribunal. Buba further held that decisions in Eguamwense $v$. Amaghizmwen ${ }^{37}$ and Ocean \& Oil Ltd v. FBIR ${ }^{38}$, confirmed that TAT was validly created and that its jurisdiction does not conflict with FHC. Further relying on section 41 of the Petroleum Profits Tax Act and paras 13 (1) \& 17 (1) of the $5^{\text {th }}$ Schedule of the FIRSEA (2007), justice Buba noted that neither of those statutes provided for a direct appeal to the Court of Appeal, unlike the VAT Tribunal which proposed to usurp, and sidestep section 251's exclusive jurisdiction to FHC. Consequently, since the TAT did not attempt to usurp the original jurisdiction of the FHC, its constitutionality was affirmed.

The above decision of Buba J in Nigerian National Petroleum Corporation (NNPC) v. Tax Appeal Tribunal $^{39}$, has been seriously attacked by some writers. Jirinwayo ${ }^{40}$ maintained that the issue borders on the interpretation of section 251 of the 1999 Constitution and the provisions of TAT. He questioned as to what is the intention of the drafters of the Constitution when the expression "...the Federal High Court shall have and exercise jurisdiction to the exclusion of any other court in civil causes and matters"? He therefore opined that the word "court" cannot be given mere literal interpretation. The threshold or test for determining when a person, body, or institution can be classified as a court depends on whether or not such body, person

34 (2010) NWLR (pt. 117) 561

35 (2006) AII FWLR (pt. 320) 1022

${ }^{36}$ Suit No. FHC/L/CS/630/2013

37 (1993) 9 NWLR (pt. 315)

38 (2011) 4 TLRN 135

${ }^{39}$ Suit No. FHC/L/CS/630/2013 
or institution exercises 'judicial or quasi-judicial power(s). Judicial power includes the exercise of coercive power, the power to distrain, compel and enforce discovery and production of attendance of witnesses or the power to enforce discovery and production of documents. Other grounds for attacking the judgment are based on the misinterpretation of section 251 of the Constitution, hence, the exclusive jurisdiction conferred on the FHC means that no court, body or institution which exercises judicial power as should have the first taste of trying any of the matters listed in section 251 of the Constitution. Only the FHC has such jurisdiction. ${ }^{41}$

On the whole, the writer completely agrees with the above stated opinion regarding the constitutionality of the TAT. Hence, the writer's total agreement with the decision in the case of TSKJ Construction Internacionals \& Anor v. Federal Inland Revenue Service ${ }^{42}$, where the learned Judge, Justice Adeniyi F.A.Ademola, questioned the constitutionality of TAT to determine civil cases and matters bordering on the revenue of the Government of the Federation and taxation of persons subject to federal laws. It held that the powers conferred on the TAT by the FIRS Act and the Tax Appeal Tribunal (Establishment) Order of November 25th 2009 (TAT) are in conflict with section 251 (1) (a) \& (b) of the 1999 Constitution. As a result, the FHC declared the TAT unconstitutional for exercising powers in areas only the FHC is authorized by the Constitution to exercise exclusive jurisdiction. This violation is not cured by subjecting the decisions of the TAT to appeals to the FHC. It further held that the argument that the TAT is merely an administrative tribunal does not hold ground because the TAT exercises judicial powers which affect the rights of litigants.

Furthermore, the fact that issues of fact determined by the Tribunal do not go the FHC may clearly qualify as "alteration, detraction or restriction" of the jurisdiction of the Federal High Court, an act forbidden by the authority of N.P.A v. Eyamba ${ }^{43}$, cited with approval in Stabilini's cas $^{44}$. It is also instructive that the alteration, detraction, or restriction as mentioned above is forbidden irrespective of current position as shown in the case of $N N P C V$. TAT ${ }^{45}$ that there is no conflict of jurisdiction.

It is the submission of Atilola ${ }^{46}$ that section 59 of the FIRS (Establishment) Act, 2007 is unconstitutional and as such, null and void. According to him:

This is in view of its obvious inconsistency with the provisions of Section 251 (1) (a), (b) and (c) of the Constitution of the Federal Republic of Nigeria 1999 (hereinafter referred to as the "1999 Constitution") which confers exclusive jurisdiction on the Federal High Court in respect of civil causes and matters relating to the revenue of the Government of the Federation.

The writer is in total agreement with the conclusion arrived by Atilola ${ }^{47}$ that the Tribunal cannot validly exercise the powers and jurisdictions purportedly conferred on it by the Act.

\section{USING ADR TO RESOLVE TAX DISPUTES IN NIGERIA}

As the courts grew, delays, formalities, technicalities, corruption and the like crept in. Similarly, the cause lists became overcrowded and court environment and sittings became intimating

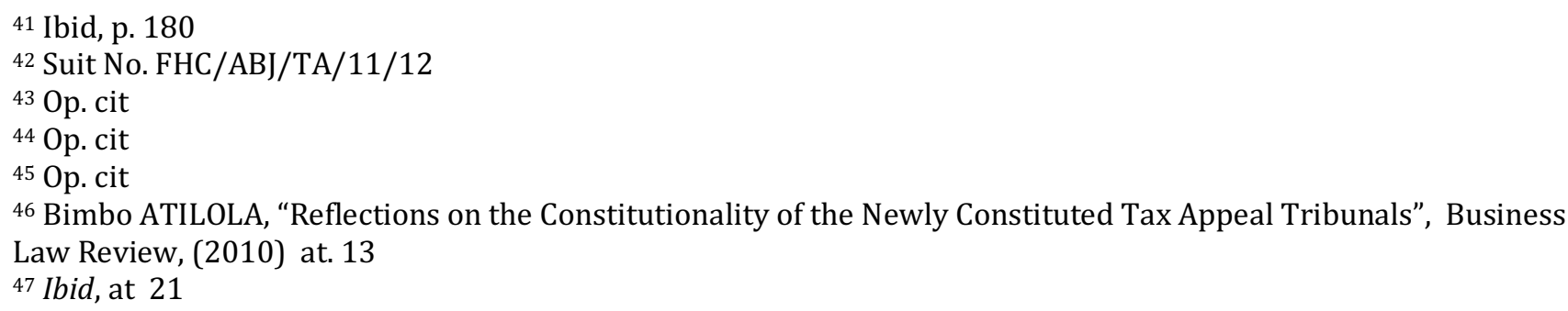


and oppressive to the uninformed. There was a realization that rights and revenge are not the focus of most disputes: many disputes involve misunderstandings, accidents or other situations where getting the problem resolved quickly is more important than placing blame. These lead to a rethinking and hence the emergence of alternative dispute resolution (ADR) processes. Thus from resolving disputes in a fixed and identifiable place called a courtroom, disputes were taken from the courtrooms to any place. Similarly, ADR represented a move away from a formal process to informal process. ${ }^{48}$

It is in view of the foregoing observations that this paper takes to resort to alternative disputes resolution (ADR) as practiced in other jurisdictions as the surest way to resolve tax disputes in Nigeria.

\section{What is Arbitration?}

It is a method of settling disputes outside the jurisdiction of any particular court. The two (or more) parties agree to settle their dispute by the decision of one or more third party neutrals of their choosing. ${ }^{49}$ Although arbitration is an alternative dispute resolution method, it is similar to litigation in that by entering into it, the parties give the right to determine the outcome of their dispute. In litigation, that third party is known as a judge, in arbitration, that third party is known as an arbitrator. ${ }^{50}$ The arbitrator or arbitral tribunal adjudicates the dispute and issues an award..$^{51}$ Unlike a negotiated settlement or mediation, an arbitral award is binding and final, foreclosing further avenues of redress..$^{52}$ Hence, where the parties do not carry out the award voluntarily, the party desiring enforcement of the award has the option to petition a court. As a general rule, the court will compel the non-compiling party to follow the arbitration decision..$^{53}$

The Arbitration and Conciliation Act, Cap. 18, L.F.N, $2004^{54}$, is the main Nigerian Statute dealing with arbitration. According to its long title, it is an Act to provide a unified legal framework for the fair and efficient settlement of commercial disputes by arbitration and conciliation, and to make applicable the Convention on the Recognition and Enforcement of Foreign Awards (New York Convention) to any award made in Nigeria or in any contracting state arising out of international commercial arbitration.

In its interpretation section, section 57 of the Arbitration and Conciliation Act defines arbitration to mean: "A commercial arbitration whether or not administered by a permanent arbitral institution".

However, Halsbury's laws of England ${ }^{55}$, defines arbitration as follows: An arbitration is the reference of a dispute or difference between not less than two parties for determination, after hearing both sides in a judicial manner, by a person or persons other than in court of competent jurisdiction.

\footnotetext{
${ }^{48}$ Paul O. IDORNIGIE, "From Alternative Dispute Resolution (ADR) To Online Dispute Resolution (ODR): Jurisdictional And Evidential Issues", a paper presented at the 2005 Annual Conference of the Nigerian Bar Association, Jos, Plateau State, Nigeria, from $28^{\text {th }}$ August $28^{\text {th }} 4^{\text {th }}$ September, 2005

${ }^{49}$ Jean-Francois POUDRET \& Sebastien BESSON, Comparative Law of International Arbitration, (2007) at 1

${ }^{50} \mathrm{H}$. RODERIC, et al, International Commercial Arbitration Advocacy, (2010) at 43

${ }^{51}$ Phillipe FOUCHARD, et al, International Commercial Arbitration 12, (1999) at 5

52 Ibid

${ }^{53}$ Alan REDFERN and Martin HUNTER, "Law and Practice of International Commercial Arbitration 2, (4th ed. 2004)

54 This Principal legislation was first enacted in 1988

${ }^{55}$ Halsbury Laws of England, 3rd Edition, vol. 2, p. 2
} 
Arbitration is dependent on the basic contract that creates it; it is therefore imperative that the arbitration agreement addresses all the specific procedural issues prior to beginning the arbitration. If the arbitration agreement lacks the procedural elements, it is possible that a valid agreement will never lead to arbitration if the parties cannot agree on procedures at the time of the dispute. ${ }^{56}$

Scholars primarily cite the following reasons when explaining the increase arbitration's popularity: predictability, neutrality of panel, expertise of panel, finality, limited discovery, less time consuming, less expensive, and generally more amicable. ${ }^{57}$

\section{The Concept of Arbitration}

The concept of arbitration is described by Redfern and Hunter thus:

The issue practice of arbitration comes to speak, naturally to primitive bodies of law; and after courts have been established by the state and a recourse to them has become the natural method of settling disputes, the practice continues because the parties to a dispute want to settle them with less formality and expense than is involved in a recourse to the courts. ${ }^{58}$

Further, Lord Mustill noted about the rudimentary nature of the arbitral process in its early history as:

Commercial arbitration must have existed since the dawn of commerce. All trade potentially involves disputes and successful trade must have a means of dispute resolution over than force. From the start, it must have involved a neutral determination, and an agreement, tacit or otherwise, to abide by the result, back by some kind of sanction. It must have taken so many forms, with mediation no doubt merging into adjudication. The story is now lost forever. Even for historical times it is impossible to piece together the details, as will readily be understood by anyone who nowadays attempts to obtain reliable statistics on the current incidence and varieties of arbitrations. Private dispute resolution has always been resolution private.

Arbitration in its modern form is still the same as what obtained in its early form. Hence, the fundamentals two or more parties, whether in anticipation of dispute or already in dispute, agreeing to nominate another private person to resolve the issues between them by arriving at a decision are still present. The private person is called an arbitrator. In the present day arbitral process, an arbitral panel will consist of one or more arbitrators, nominated for or on behalf of the parties. The task before the arbitral panel is to evaluate the evidence and the argument of the parties and then to arrive at a decision on the dispute. The decision is given in writing, in the form of an award.

\section{ISSUES TO BE DETERMINED BEFORE TAX MATTER SHOULD BE ARBITRABLE}

Basically, when scholars discuss whether a tax dispute should be determined by arbitration, they often do so by using the word 'arbitrable'. A dispute is arbitrable if it meets two criteria: 1) the parties must be on a footing relative to each other and to the arbitration tribunal such

\footnotetext{
56 Alan REDFERN and Martin HUNTER, Law and Practice of International Commercial Arbitration, at 9

57 James H. CARTER, Dispute Resolution and International Agreements, in International Commercial Agreements (1995) at 445

58 Alan REDFERN and Martin HUNTER ,"Law and Practice of International Commercial Arbitration, footnote 56 at 22
} 
that the tribunal can make a reasonably enforceable award, ${ }^{59}$ and 2 ) the subject matter of the dispute must be conducive to arbitration. ${ }^{60}$

Though arbitration is very time efficient, part of the reason for that time efficiency is that arbitration streamlines and limits procedural elements such as discovery. Arbitration sacrifices fairness for efficiency compared with traditional court proceedings. In a tax dispute, the question becomes: should a process that sacrifices some due process to procedural efficiency be used to resolve issues that are often among the most complex of all civil disputes? As the complexity of a dispute increases, so to does the possibility of a miscarriage of justice if both the parties and the arbitral tribunal do not have adequate time to work through all of the relevant issues. Thus, the question arises can a tax dispute be an arbitrable issue, if fairness must be sacrificed?

Secondly, another issue that could render tax disputes not arbitrable is arbitral error. In undertaking arbitration, both parties agree to forgo certain judicial processes, such as discovery and appeal as a matter of informed self interest. ${ }^{61}$ Accordingly, a taxpayer who is bound to similar conditions without consent has simply had his or her access to those judicial rights curtailed by administrative fiat.

According to Ezejiofor, the disputes that can be referred to arbitration:

Disputes that can be referred must be justiciable issues which can be tried as civil matters. They must be disputes that can be compromised by way of accord and satisfaction. These include all matters in dispute about any real or personal property, disputes as to whether contract has been breached by either party thereto, or whether one or both parties have been discharged from further performance thereof...IIssues in an action before a court can, if the parties agree, and with leave of court, be referred. Specific questions of law, such as the construction of a document, may be referred to arbitration. ${ }^{62}$

Furthermore, Ezejiofor, on the other hand stated the issues that cannot be referred to the arbitration:

Disputes arising out of illegal transactions cannot be referred. Thus, a difference relating to a contract which is illegal for being inconsistent with a government order cannot be referred. An award arising from such reference cannot be enforced and may be set aside. Disputes arising out of void transactions such as wagering and gaming contracts, cannot be referred. An indictment for an offence of public nature cannot be referred. It is a settled policy of the law that an arbitrator should not be empowered to settle a criminal charge which is a matter of public concern. ${ }^{63}$

\section{Arbitrability of Tax Disputes in Nigeria}

In a regulated business environment, tax liability disputations are fairly common. In Nigeria, the common practice is that the tax disputes are usually resolved at the Tax Appeal Tribunal (TAT), an administrative tax complaints tribunal, from which appeals may lie to the Federal High Court (FHC). However, until recently, there has been no clear and definitive judicial

\footnotetext{
${ }^{59}$ Fouchard, et al, op. cit, at 312-313

60 Jean-Francois POUDRET and Sebastien BESSON, Comparative law of International Arbitration (2007) footnote 49

61 William W. PARK, Arbitration of International Business Disputes: Students in Law and Practice (2006) at 7

62 EZEJIOFOR, The Law of Arbitration in Nigeria, (1997) at 3

$63 \mathrm{Ibid}$, at. 4
} 
pronouncement on arbitrability of tax disputes in Nigeria. This segment examines a recent Court of Appeal decision dealing with arbitrability of tax disputes. It was the decided case of Shell (Nig) Exploration and Production Ltd \& 3 Others v. Federal Inland Revenue Service ${ }^{64}$ where the court answered in the affirmative tax disputes in Nigeria are arbitrable or not.

\section{Facts of the case}

The issue involve dispute between contracting parties to Production Sharing Contracts (PSC) pertaining to certain Oil Mining Lease in Nigeria. Under the contractual arrangement between the parties, the contractor has the responsibility of preparing petroleum profit tax returns and submitting to the Nigerian National Petroleum Corporation (NNPC) for filing with FIRS. In the purported breach of the contractual arrangements, NNPC failed to file tax returns prepared and submitted to it by the contractor. In some instances, NNPC unilaterally amended tax returns without recourse to the contractor. Premised on the alleged breach, the contractor commenced separate arbitration proceedings against NNPC in accordance with the relevant provisions of the PSC. Arbitrators were appointed and the parties made substantial progress in the proceedings.

However, FIRS instituted court action challenging the propriety of the arbitration proceedings on the basis that the issues in dispute are tax related and, therefore, inarbitrable.

The principal issues that fell for the determination by the Court of Appeal were:

a. Whether the notice of arbitration by which Contractors/Appellants initiated the arbitration was validly issued?

b. Whether FIRS had sufficient interest or right (locus) in the subject matter of the arbitration?

c. Whether the claims submitted to the arbitration were contractual matters or tax matters; and if so, whether tax matters are arbitrable in Nigeria?

The main trust of segment concerns with arbitration of tax disputes. Hence, we are concerned with the third issue, i.e. whether the claims before the arbitral tribunal are purely contractual disputes arising under the parties' contract (the PSC), and are therefore arbitrable and the issues relating to computation of Petroleum Profit Tax were only ancillary reliefs in the course of the determination of the private contractual rights of the parties under the PSC.

In deciding the arbitrability of tax disputes, the court referred to section 251 (1) of the 1999 Constitution and held as follows:

The provision under 251 of the Constitution is a clear spelling, that when it comes to the revenue of the Government of Nigeria or its organ and on matters pertaining to taxation of companies and other bodies carrying on business in Nigeria, it is the Federal High Court that has exclusive jurisdiction to adjudicate upon same. There is no dispute abut it. Therefore, the claim filed before the tribunal, being substantially tax disputes, the tribunal would not have jurisdiction to pronounce upon them as they are not arbitrable.

\section{ARBITRATION UNDER THE NIGERIAN LAW}

In Nigeria, the main arbitration legislation is the Arbitration and Conciliation Act ${ }^{65}$ (ACA). The Act does not provide clear guidance on the type of disputes that cannot be referred to arbitration. However, section 35 provides that the ACA will not affect any law in relation to

64 (Unreported) CA/A/208/2012; judgment delivered on 31 August 2016

${ }^{65}$ Cap. A 18, Laws of the Federation of Nigeria, 2004 
which 'certain disputes may not be submitted to arbitration'. In terms of enforcement, one of the grounds for refusing recognition and enforcement of an award under ACA is where the court finds that the subject matter of the dispute is not capable of settlement by arbitration under the laws of Nigeria. ${ }^{66}$

It is obvious that from the aforesaid, tax disputes are not arbitrable in Nigeria, hence, resort have to be had to other types of ADR in resolving tax disputes in Nigeria: negotiation and mediation respectively.

\section{Negotiation}

Here, participation is voluntary and there is no third party who facilitates the resolution process. However, a third party is like a chaplain or organizational ombudsman or social worker or a skilled friend may be coaching one or both of the parties behind the scene, a process called "Helping people Help themselves." 67

In the United States, a taxpayer can initiate the Appeals by filing a protest letter. An Appeals officer then considers the merits of the case and the time and cost of litigation to arrive at a settlement figure. ${ }^{68}$ An Appeals conference is then scheduled so that the Appeals officer and the taxpayer can attempt to negotiate a mutually acceptable settlement. ${ }^{69}$ It should be noted that the primary focus of the Appeals process is negotiation. That is, the taxpayer and Appeals officer try to settle the dispute "through persuasion regarding the merits of their respective positions." ${ }^{\prime \prime 0}$

\section{Mediation}

Mediation is a flexible process conducted confidentially in which a neutral person known as the mediator actively assists parties in working towards a negotiated agreement of a dispute with the parties in ultimate control of the decision to settle and the terms of resolution. ${ }^{71}$ In other words, there is a third party, mediator who facilitates the resolution, typically known as a "mediator proposal", but does not impose a resolution on the parties. Contrary to what obtains in Nigeria, in the United States, mediation is available throughout dispute resolution process: first while the case is under the jurisdiction of the IRS, and second, when the case is in the Tax Court's jurisdiction. ${ }^{72}$

Mediation can be thought of as "negotiation plus". That is, it takes the principle of negotiation (i.e. evaluation and persuasion) and adds a third party to facilitate an agreement. The mediator is essentially a third party through whom the parties can engage in negotiation. ${ }^{73}$ The success of mediation, then, depends on the presence of open communication ${ }^{74}$ and trust among the participants. The importance of mediator impartially centres on the fact that one of the mediator's roles is to evaluate the merits of the claims of each party and to engage the parties

\footnotetext{
66 Ibid, section 52 (2) (a)

67 Helping People Help Themselves", Negotiational Journal, (July, 1990) at 239-248

68 Thomas Carter LOUTHAN \& Steven C. WRAPPE," Building a Better Resolution: Adopting IRS Procedures to Fit the Dispute", 13 Tax Notes International (1996) at 1473

69 The Appeals conference is designed to minimize tension and maximize convenience for the taxpayer.

${ }^{70}$ Alan H. Friedman, Should the State Tax Community Use Alternative Dispute Resolution Processes? Or, Should We Just Keep on Throwing Stones? , 22 State Tax Notes 765, 766 (2001)
}

74 Alexei P. MOSTOVOI, “Tax Mediation: Is It Just a Test”?, 13 Tax Notes International, (1996) at 1875 
in discussion and compromise. ${ }^{75}$ Ultimately, parties will be less willing to fully disclose information and wholly accept the mediator's evaluation of their claim if they have the impression that the mediator is partial to the other side. Therefore, with the preservation of confidentiality and impartiality, information can be freely shared among the mediation participants, which in turn, will allow the mediator to gain an accurate understanding of the claims. ${ }^{76}$

Mediation is characterized by its informality and flexibility and is also voluntary and nonbinding. The ability to mold the process to the needs of the parties and the use of informal rules of evidence make mediation particularly attractive. Furthermore, because it is nonbinding, the taxpayer has little to loss-in the event that an acceptable settlement is not reached, litigation can still be pursued. ${ }^{77}$ Second, mediation forces both parties to seriously examine their claims as they prepare for the mediation session and ensures that a neutral third party will examine the merits of each side's claims anew, providing an untainted perspective in the dispute. Mediation provides the taxpayer and the tax authority an opportunity to resolve the dispute in a relatively fast and cost-effective manner.

\section{VOLUNTARY ASSETS AND INCOME DECLARATION SCHEME (VAIDS)}

The Nigerian Ministry of Finance defines VAIDS as a time limited opportunity for taxpayers to regularize their status relating to previous tax periods. In exchange for fully and honestly declaring previously undisclosed assets and income, tax payers will benefit from forgiveness of overdue interest, and penalties, and the assurance that they will not face criminal prosecution for tax offence or be subject to tax investigations. VAIDS ushers in opportunity to increase the nation's general awareness and compliance. ${ }^{78}$ It is a clarion call on tax defaulters to redeem themselves to avoid sanctions. ${ }^{79}$

On the 29 June, 2017, the Acting President of Nigeria, Professor Yemi Osinbajo, SAN, formally launched VAIDS through Executive Order Number 004 of 2017. It is an initiative designed to encourage voluntary disclosure of previously undisclosed assets and income for the purpose of payment of all outstanding tax liabilities The Introduction of VAIDS aims at discouraging tax evasion by taxpayers in Nigeria. Its vision is a time limited opportunity for taxpayers to regularize their tax status relating to previous tax periods and pay any taxes due. In exchange for fully and honestly declaring previously undisclosed assets and income, tax payers will benefit from forgiveness of overdue interest, penalties, and the assurance they do not face criminal prosecution for tax offences or tax investigations. In other words, the scheme encourages voluntary disclosure of previously undisclosed assets and income for the purpose of payment of all outstanding tax liabilities. The scheme will offer a limited waiver ${ }^{80}$ for declaration within the specified period of time. The Scheme will be implemented by the Federal Inland Revenue Service (FIRS) in collaboration with all the 36 States Internal Revenue Services and the FCT IRS. It commences on 1 July 2017 for period of 9 (nine) months. Among its objectives ${ }^{81}$, are:

\footnotetext{
75 Stephen J.WARE o. cit footnote 73.

${ }^{76}$ Alexei P. MOSTOVOI, op. cit, at 1875 footnote 74

77 Erin M. COLLINS, Mediation Should Be Available to All Taxpayers, Tax Notes Today, August 8, (Lexis 2002) TNT at 177

78 Definition given by the Federal Ministry of Finance, also available at www.firs.gov.ng accessed on 26 September 2019

${ }^{79}$ Ayodele ZUBAIR, Last Chance for Tax Offenders, being a paper presented at the International Conference of African Tax Administrations Forum (ATAF), Abuja on 28 September, 2017

$8029 \%$ waiver on overdue taxes if they take advantage of VAIDS

81 VAIDS, available at www.pwc.com/ng accessed on 26 September 2019
} 
a. Increasing Nigeria's tax to GDP ratio from $6 \%$ to $15 \%$ by 2020 ;

b. Broadening the Federal and State tax brackets ${ }^{82}$;

c. Curbing non-compliance with existing tax laws and discouraging use of tax havens, and

d. Discouraging illicit financial flows and tax evasion

For a better and fuller understanding of the Executive Order, it is necessary to set down some of the fundamental provisions under it.

\section{Eligibility to participate ${ }^{83}$}

The Scheme is open to and targeted to all persons and entities that are in default of their tax liabilities in anyway whatsoever including those below:

a. Earn an income or own assets but are yet to register with the relevant tax authorities;

b. Are registered taxpayers who have additional disclosures to make or need to amend prior disclosures; and/or are registered but have not been filing returns;

c. Have not been fully declaring their taxable income and assets;

d. Have been underpaying or under remitting;

e. Are under a process of tax audit or investigation with relevant Tax Authority, and/or

f. Are engaged in a tax dispute with the relevant Tax Authority but are prepared to settle the tax dispute out of court.

\section{Reliefs/Benefits ${ }^{84}$}

Any taxpayer, who truthfully and voluntarily declares his assets and income, complies with the regulations and guidelines and pays all outstanding taxes shall obtain the following benefits:

a. Immunity from prosecution for tax offences;

b. Immunity from tax audit;

c. Waiver of interest;

d. Waiver of penalties and

e. Option of spreading payment of outstanding liabilities over a maximum period of three years as may be agreed with the relevant tax authority.

Provided however that the remission or waiver granted under these regulations shall not prejudicially affect or invalidate any court order or judgment already obtained in respect of any default in payment of tax for which interest and/or penalty have already accrued.

\section{Consequences of failure to comply ${ }^{85}$}

Failure of any defaulting taxpayer to truthfully and promptly take advantage of this scheme shall at the expiration of the Scheme result in the following consequences:
a. Liability to pay in full, the principal sum due;
b. Liability to pay all interests and penalties arising there from;
c. Liability to be prosecuted in accordance with relevant extant laws for tax offences;
d. Withdrawal of any reliefs, which may have been granted to the participant
e. Liability to undergo comprehensive tax audit; and
f. Any sum paid in relation to the Scheme may be counted as part payment of any further outstanding tax in respect of undisclosed information.

\footnotetext{
82 Only 214 individuals nationwide paid \#20 million or more in tax annually

83 See Executive Order, No. 004, 2017, Paragraph 4

84 Ibid, Paragraph 6

85 Ibid, Paragraph 8
} 
The legal basis for the Scheme is an executive Order signed into law by the Vice President in his acting capacity and a Memorandum of Understanding signed between the federal and state governments. The Scheme is applicable to all persons (individuals, companies, executors, trustees, partnerships etc) that are liable to tax in Nigeria. Taxes covered include Companies Income Tax, Personal Income Tax, Withholding Tax, Petroleum Profits Tax, Capital Gains Tax, Value Added Tax, Stamp Duties, Tertiary Education Tax and NITDA levy.

However, taxpayers who fail to participate in the Scheme will be investigated and if found culpable will be subject to criminal prosecution. A 'name and shame' list of tax evaders will be published. Government will rely on tax intelligence gathering, whistle-blowing and various international conventions and multilateral agreements to obtain information required for prosecution of defaulting taxpayers or those who make false declarations. VAIDS offers a time limited opportunity to taxpayers to regularize their tax status relating to past periods, in terms of registration, filing of returns, assessment and payment of all taxes due. Thus, the Scheme offers companies and entrepreneurs whose tax affairs are yet to be settled, a window to make amends from 1 July 2017 to 31 March 2018

\section{RECOMMENDATIONS}

The constitutional issues surrounding TAT should be urgently looked into with a view to clearly distinguishing between its jurisdictional powers and the FHC jurisdictions in resolving tax disputes in Nigeria. Furthermore, the relevant amendments should be made to FHC resort into using ADR in tax dispute resolution. Taxpayers should be adequately enlightened about the newly introduced VAIDS in order to take advantage of the amnesty offered by the Federal Government before it expires in March 2018. Furthermore, there is the need for a constitutional amendment to accommodate the creation of a specialized tax court. A constitutionally recognized tax court is what Nigeria needs now as it helps in resolving tax dispute with speed and efficiency. ${ }^{86}$ Alternatively, if the Constitution cannot be easily amended to create a specialized tax court, traditional courts like the FHC should create specialized chambers within the general court system. ${ }^{87}$

\section{CONCLUSION}

Disputes are inevitable in any social context. Human beings are found to disagree on and at almost every point in life. As long as human beings interact, however, disagreements and disputes are bound to occur especially in tax matters. The spate of disputes worldwide at the turn of century has particularly been accentuated by the speed, complexity and frequency of local and global transactions. The fact that disputes occur should not be the crux of the matter, rather their management and resolution. ${ }^{88}$ One point therefore on which the global community agrees on in particular is the need for a legal system that meets up with contemporary trends. The need for a universally applicable, cost effective, user-friendly, and speedy means of dispute resolution is imperative to cope with the speed and complexity of disputes that arise. ${ }^{89}$ Nigeria, as a country cannot therefore operate in isolation, hence the introduction of ADR in its tax dispute resolution processes should be imminent and mandatory. Therefore, there is the need for Nigeria as a country to adopt the global trend in resolving its tax disputes. The advent of

\footnotetext{
86 Ibid.

87 Idid

88 AINA , "THE Multi-Door Courthouse Concept: A Silent Revolution in Legal Practice", being a paper presented at the 2005 Annual Conference of the Nigerian Bar Association, Jos, Plateau State, from 28 ${ }^{\text {th }}$ August-4 ${ }^{\text {th }}$ September, 2005

89 Peter A.ANYEBE, “Alternative Dispute Resolution and Information Technology as Tools for Judicial Reform in Accessing and Dispensing Justice in Nigeria”, Apogee Journal of Business, Property \& Constitutional Law, (January-March, 2010) at. 54
} 
VAIDS as a new push for tax compliance or an amnesty programme in Nigeria is also in 'all four' with the proposals of OECD of 2010. 